Zeszyty Naukowe Szkoły Głównej Gospodarstwa Wiejskiego

Ekonomika i Organizacja Gospodarki Żywnościowej nr 108, 2014: 103-117

Grzegorz Trzciński, Piotr Leciejewski

Wydział Leśny

Szkoła Główna Gospodarstwa Wiejskiego w Warszawie

\title{
Realizacja wielofunkcyjnej gospodarki leśnej z wykorzystaniem funduszy europejskich przez Państwowe Gospodarstwo Leśne
}

\section{Wstęp}

Wizja Roberta Schumana (1886-1963) zwana „planem Schumana” zjednoczonej i bezpiecznej Europy stała się faktem [http://europa.eu/about-eu/eu-history/1945-1959/foundingfathers/schuman/index_pl.htm]. Od pierwszych działań zmierzających do powstawania obecnej struktury Unii Europejskiej (UE) minęło już ponad 60 lat. W kwietniu 1951 roku sześć państw w Paryżu podpisało traktat ustanawiający Europejską Wspólnotę Węgla i Stali, a następnie w marcu 1957 roku Traktat Rzymski powołujący Europejską Wspólnotę Gospodarczą (EWG) i Europejską Wspólnotę Energii Atomowej (Euratom). Z sześciu państw założycielskich, zwanych „rdzeniem” [Ładyga 2007], Wspólnota Europejska rozszerzyła się do dwudziestu siedmiu państw członkowskich. Polska należy do UE od 1 maja 2004 roku na mocy tzw. traktatu akcesyjnego podpisanego 16 kwietnia 2003 roku w Atenach. Jednak proces integracji Polski rozpoczął się już dziewięć lat wcześniej (IV 1994 r.) w Atenach po złożeniu przez nasz kraj wniosku o członkostwo w UE, który został następnie przyjęty przez państwa członkowskie UE podczas konferencji w Essen 9-10 grudnia 1994 roku.

Ideą Roberta Schumana było stworzenie bezpiecznej Europy poprzez wspólną gospodarkę strategicznych jej działów (węgla i stali), które w następnych latach rozszerzano na nowe dziedziny gospodarki i życia obywateli UE poprzez realizację podpisanych kolejnych traktatów (np. amsterdamskiego, nicejskiego, lizbońskiego). Unia Europejska, chcąc zapewnić realizację wspólnych celów wynikających z przyjętych traktatów uruchomiła wiele funduszy umożliwiających finansowanie działań związanych z korygowaniem podstawowych dysproporcji regionalnych we Wspólnocie Europejskiej poprzez niwelowanie różnic w poziomach rozwoju oraz zacofania regionów w różnych dziedzinach gospodarczych i spo- 
łecznych krajów członkowskich UE. Na mocy Traktatów Rzymskich jako pierwsze zostały powołane Europejski Fundusz Społeczny (EFS), Europejski Fundusz Orientacji i Gwarancji Rolnej (obecnie Europejski Fundusz Rolny Rozwoju Obszarów Wiejskich (EFRROW) i Europejski Fundusz Gwarancji Rolnej (EFGR), a w następnych latach powołano Europejski Fundusz Rozwoju Regionalnego (EFRR) i Fundusz Spójności (FS).

W latach 2004-2006 Polska wykorzystywała fundusze unijne do finansowania sektorowych programów operacyjnych (SPO) realizowanych w ramach Narodowego Planu Rozwoju 2004-2006: Sektorowy Program Operacyjny (SPO) Wzrost Konkurencyjności Przedsiębiorstw, SPO Rozwój Zasobów Ludzkich, SPO Transport, Zintegrowany Program Operacyjny Rozwoju Regionalnego, SPO Restrukturyzacja i Modernizacja Sektora Żywnościowego oraz Rozwój Obszarów Wiejskich, SPO Rybołówstwo i Przetwórstwo Ryb, PO Pomoc Techniczna, Strategia Wykorzystania Funduszu Spójności. Fundusze europejskie w ponad $80 \%$ finansowały (finansuja) krajowe programy operacyjne (PO) realizowane w ramach Narodowej Strategii Spójności 2007-2013: PO Innowacyjna Gospodarka, PO Kapitał Ludzki, PO Infrastruktura i Środowisko (PO IiŚ), 16 Regionalnych Programów Operacyjnych (RPO), PO Rozwój Polski Wschodniej, PO Program Rozwoju Obszarów Wiejskich (PROW), PO Europejskiej Współpracy Terytorialnej (PO EWT), PO Ryby, PO Pomoc Techniczna [www.mrr.gov.pl].

Trzeba także wspomnieć o wielu innych instrumentach finansowych z jakich korzystała i korzysta Polska po przystąpieniu do struktur UE, a są to między innymi: INTERREG, LIFE i LIFE+, Mechanizm Finansowy Europejskiego Obszaru Gospodarczego (MF EOG), Norweski Mechanizm Finansowy (NMF). Wszystkie ww. programy zawierają osie priorytetowe i działania, które pozwalają na realizację wielofunkcyjnej gospodarki leśnej przez jednostki PGL LP na obszarach NATURA 2000, a szczególnie w dziedzinach priorytetowych UE odnoszących się do środowiska naturalnego i jego ochrony.

\section{Cel i zakres}

Wykorzystanie dostępnych środków i składanie wniosków przez beneficjentów zależą w dużej mierze od posiadanej wiedzy na ich temat. Dlatego autorzy podjęli się analizy dostępnych środków możliwych do wykorzystania przez jednostki PGL LP. Celem pracy była analiza wykorzystania przez jednostki PGL LP środków finansowych $\mathrm{z}$ różnych programów krajowych finansowanych przez fundusze unijne oraz europejskie instrumenty finansowe. W ramach pierwszego etapu analiz określono programy krajowe i ich osie priorytetowe oraz działania z perspektywy finansowej 2007-2013, w których jednostki PGL LP były wy- 
mieniane jako przypuszczalni beneficjenci. Na tej podstawie określono dostępne środki finansowe, o jakie mogły występować nadleśnictwa, regionalne dyrekcje LP (RDLP) czy Dyrekcja Generalna LP (DGLP). Z okresu finansowania 2004-2006 przeanalizowano środki bezpośrednio przeznaczone dla nadleśnictw PGL LP w Sektorowym Programie Operacyjnym „Restrukturyzacja i Modernizacja Sektora Żywnościowego oraz Rozwój Obszarów Wiejskich 2004-2006”.

Dostępne środki dla PGL LP określono na podstawie dokumentów programów krajowych zawierających opisy osi priorytetowych poszczególnych działań z zakresem możliwych realizacji i kosztów kwalifikowanych oraz listy przypuszczalnych beneficjentów. Dokumenty uzyskano ze strony www.funduszeeuropejskie.gov.pl oraz z poszczególnych województw dla szesnastu RPO. Ogólne dane dotyczące faktycznego wykorzystania środków, a więc podpisanie umów z instytucjami wdrażającymi oraz zaawansowanie realizacji działań określono na podstawie dostępnych danych ze stron internetowych instytucji wdrażających (np. www.arimr.gov.pl, www.ckps.lasy.gov.pl, www.nfosigw.gov.pl). Szczegółowe dane dotyczące realizacji: temat działania, ilość wykonanych obiektów przez poszczególne RDLP i nadleśnictwa zebrano $\mathrm{z}$ analiz terenowych przy współpracy jednostek PGL LP.

\section{Wyniki badań i dyskusja}

\section{Środki finansowe dostępne dla jednostek PGL LP}

Jednostki PGL LP w ramach działania 21 Sektorowego Programu Operacyjnego „Restrukturyzacja i Modernizacja Sektora Żywnościowego oraz Rozwój Obszarów Wiejskich 2004-2006" (SPO PROW 2004-2006) mogły starać się o środki finansowe w kwocie 53,232 mln zł. Wnioski mogły złożyć nadleśnictwa $\mathrm{z}$ terenów, na których wystąpiła klęska żywiołowa (schemat A) i sąsiadujące (schemat B), co przedstawiono w tabeli 1.

Tabela 1

Liczba nadleśnictw zakwalifikowanych do działania 21 w SPO PROW 2004-2006

\begin{tabular}{|l|c|c|c|}
\hline \multirow{2}{*}{ Klęska żywiołowa } & \multicolumn{2}{|c|}{ Liczba nadleśnictw } & \multirow{2}{*}{ Regionalna Dyrekcja LP } \\
\cline { 2 - 3 } & schemat A & schemat B & Olsztyn i Białystok \\
\hline Huragan 4.07.2002 & 9 & 6 & Krosno \\
\hline Huragan 2003-2004 & 15 & 6 & Katowice, Zielona Góra, Kraków \\
\hline Powódź lipiec 2004 r & 9 & - & \multirow{2}{*}{ relan } \\
\hline
\end{tabular}

Źródło: Rozporządzenie Ministra Rolnictwa i Rozwoju Wsi z dnia 8 września 2004 r. w sprawie uzupełnienia Sektorowego Programu Operacyjnego „Restrukturyzacja i modernizacja sektora żywnościowego oraz rozwój obszarów wiejskich 2004-2006”. 
W okresie finansowania 2007-2013 jednostki PGL LP, jako beneficjenci środków, mogły starać się o finansowanie działań w ramach programów krajowych: z szesnastu RPO na łączną sumę 3045,0 mln euro (w tym 2056,7 z EFRR), z PO IiŚ środki z ogólnej puli 972,4 mln euro (z funduszy UE 826,6 mln euro), z PO PROW przewidziano dla nadleśnictw PGL LP $140 \mathrm{mln}$ euro (112 mln euro z EFRROW), z PO EWT 196,39 mln euro, z LIFE+ 86,7 mln euro (rys. 1).

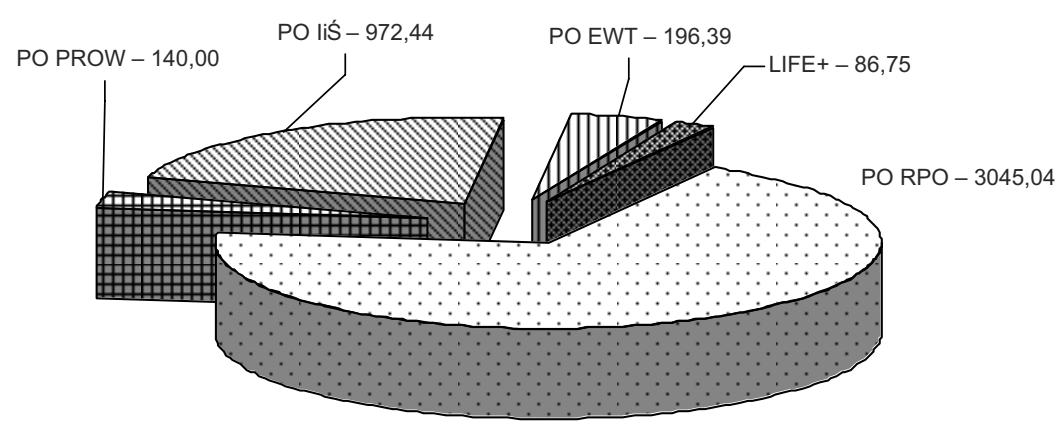

\section{Rysunek 1}

Środki finansowe dostępne dla PGL LP w programach operacyjnych [mln euro]

Źródło: Opracowanie własne na podstawie danych źródłowych instytucji nadzorujących.

Są to całkowite sumy wymienione $\mathrm{w}$ osiach priorytetowych działania, w których jednostki PGL LP zostały wymienione jako przypuszczalni beneficjenci i zawierają one fundusze zarezerwowane na realizację projektów kluczowych i indywidualnych zmniejszających dostępne środki dla ogółu beneficjentów. Wyjątkiem jest tu PO PROW, w którym w osi drugiej, działanie 226 przewidziano jako beneficjentów tyko nadleśnictwa PGL LP.

W RPO Mazowsza i RPO Podkarpackiego przewidziano najwięcej środków (422,8 i 415,8 mln euro) na finansowanie działań, o które mogły występować jednostki PGL LP, przy czym największe $(327,5 \mathrm{mln}$ euro) dofinansowanie z EFRR zostało przyznane RPO Podkarpackim (rys. 2). Jednostki PGL LP $\mathrm{z}$ terenu województwa opolskiego miały najmniejszą pulę środków finansowych - 40,2 mln euro (z EFRR 19,4 mln euro), o jakie mogły składać wnioski. Średnia dostępnych środków dla PGL LP w RPO wyniosła 190,3 mln euro. Na poziomie średniej krajowej przewidziano środki w RPO województw podlaskiego, świętokrzyskiego i wielkopolskiego. Środki z RPO o jakie mogły starać się jednostki PGL LP (nadleśnictwa, RDLP) głównie określone były w osiach priorytetowych związanych z infrastrukturą turystyczną i zwiększeniem walorów regionów (np. oś , Turystyka i kultura” lub „Turystyka i dziedzictwo kulturowe”) oraz ochroną i poprawą stanu środowiska naturalnego [Trzciński 2009]. 


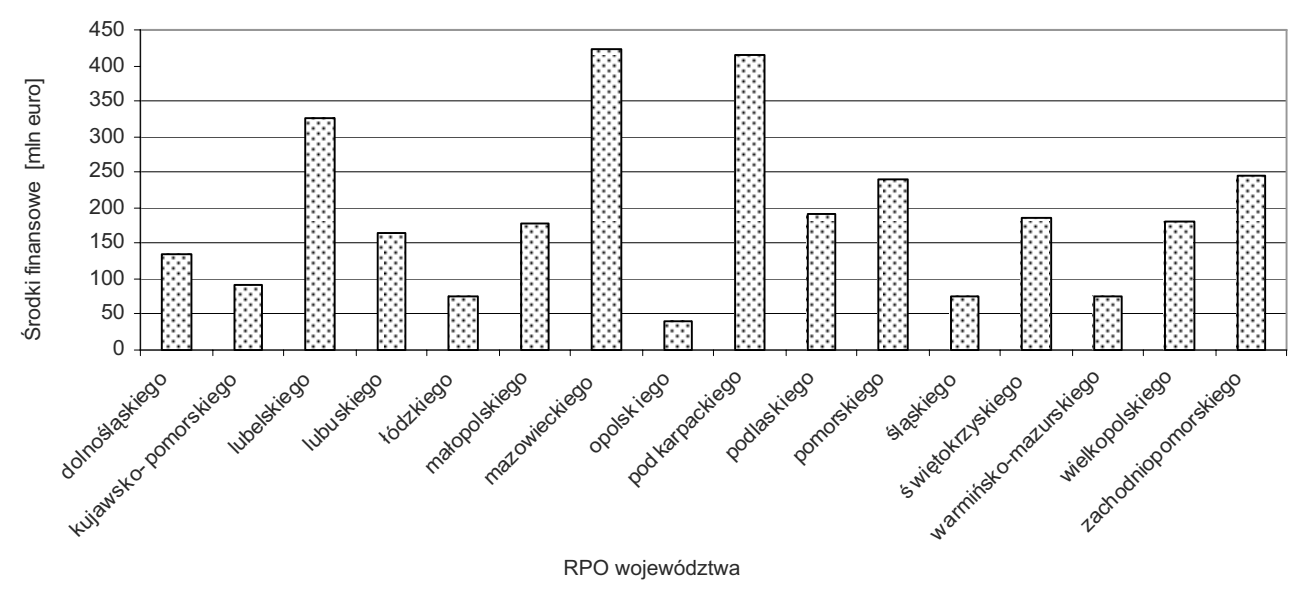

Rysunek 2

Środki finansowe możliwe do pozyskania przez PGL LP w ramach RPO województw Źródło: Opracowanie własne na podstawie danych źródłowych programów RPO.

W pierwszej kolejności w ramach wyżej wymienionych osi priorytetowych nadleśnictwa mogły realizować zadania zmierzające do wzrostu znaczenia turystyki w rozwoju regionalnym poprzez wykorzystanie walorów turystycznych regionów i rozbudowę ogólnodostępnej infrastruktury turystycznej. W drugiej kolejności (nie znaczy to, że o mniejszym znaczeniu) realizowane mogły być działania związane z ochroną środowiska, polegające na: gospodarce odpadami (likwidacja „dzikich wysypisk śmieci”), retencjonowaniu wód, rekultywacji obszarów zdegradowanych, ochronie bioróżnorodności i terenów cennych przyrodniczo oraz edukacji ekologicznej.

W PO PROW w działaniu 226 (druga oś priorytetowa - Poprawa środowiska naturalnego i obszarów wiejskich) „Odtwarzanie potencjału produkcji leśnej zniszczonego przez katastrofy oraz wprowadzanie instrumentów zapobiegawczych" nadleśnictwa PGL LP są jedynymi beneficjentami środków. Przewidziano składanie wniosków w ramach dwóch schematów: I i II, które różniły się zakresem kosztów kwalifikowanych. Schemat I dostępny był dla nadleśnictw, na terenie których wystąpiła katastrofa naturalna lub klęska żywiołowa i zostały wymienione w rozporządzeniu Ministra Rolnictwa i Rozwoju Wsi z możliwością realizacji zadań związanych $\mathrm{z}$ odnowieniem, pielęgnacją i ochroną powierzchni uszkodzonych drzewostanów, ochroną cennych obiektów przyrodniczych, wykonaniem obiektów zapewniających realizację funkcji społecznych lasu, wzmocnieniem systemu ochrony przeciwpożarowej obszarów leśnych [Dz. U. z 2008 r. Nr 103, poz. 658)]. O dostępności środków w ramach schematu II, które jedynie mogły być przeznaczone na wzmocnienie systemu ochrony przeciwpożarowej, decydowało zakwalifikowanie obszaru leśnego do I lub II kategorii zagrożenia pożarowego (Klasyfikacja IBL z 2006 r.). Nadleśnictwa 
z rejonu nowosądeckiego i krośnieńsko-przemyskiego (33 jednostki), których obszary leśne zakwalifikowano do trzeciego stopnia zagrożenia pożarowego, zostały wykluczone ze schematu II na całym swoim obszarze lub częściowo, co nie wykluczało zaliczenia niektórych nadleśnictw do schematu I.

W ramach PO EWT realizowanych jest siedem programów współpracy przygranicznej, a tylko w dwóch szczegółowe opisy osi priorytetowych wymieniaja jednostki PGL LP jako możliwych beneficjentów w zakresie działań związanych z poprawą infrastruktury przygranicznej i stanu środowiska z pulą środków 196,39 mln euro. Pierwszym programem jest Europejska Współpraca Terytorialna Krajów Meklemburgia - Pomorze Przednie/ Brandenburgia i Rzeczpospolitej Polskiej (województwo zachodniopomorskie) z dwiema osiami priorytetowymi i alokacją środków:

- wspieranie działań na rzecz infrastruktury służącej współpracy transgranicznej i poprawie stanu środowiska na obszarze pogranicza $(55,38 \mathrm{mln}$ euro z EFRR),

- wspieranie transgranicznych kontaktów gospodarczych i zacieśnienie współpracy gospodarczo-naukowej (29,95 mln euro z EFRR).

\section{Tabela 2}

Dostępne środki dla PGL LP w ramach PO liś

\begin{tabular}{|c|c|c|c|}
\hline \multirow[t]{2}{*}{ Oś priorytetowa } & \multirow[t]{2}{*}{ Działanie } & \multicolumn{2}{|c|}{$\begin{array}{l}\text { Alokacja środ- } \\
\text { ków [mln euro] }\end{array}$} \\
\hline & & ogółem & z UE \\
\hline $\begin{array}{l}\text { II. Gospodarka od- } \\
\text { padami i ochrona } \\
\text { powierzchni ziemi }\end{array}$ & $\begin{array}{l}\text { 2.2. Przywracanie terenom zdegradowanym war- } \\
\text { tości przyrodniczych i ochrona brzegów mor- } \\
\text { skich }\end{array}$ & 235,29 & 200,00 \\
\hline \multirow{3}{*}{$\begin{array}{l}\text { III. Zarządzanie zaso- } \\
\text { bami i przeciwdzia- } \\
\text { łanie zagrożeniom } \\
\text { środowiska }\end{array}$} & $\begin{array}{l}\text { 3.1. Retencjonowanie wody i zapewnienie bezpie- } \\
\text { czeństwa przeciwpowodziowego }\end{array}$ & 607,05 & 516,00 \\
\hline & $\begin{array}{l}\text { 3.2. Zapobieganie i ograniczanie skutków zagro- } \\
\text { żeń naturalnych oraz przeciwdziałanie po- } \\
\text { ważnym awariom }\end{array}$ & 30,08 & 25,57 \\
\hline & 3.3. Monitoring środowiska & 17,91 & 15,22 \\
\hline \multirow{3}{*}{$\begin{array}{l}\text { V. Ochrona przyrody } \\
\text { i kształtowanie pod- } \\
\text { staw ekologicznych }\end{array}$} & $\begin{array}{l}\text { 5.1. Wspieranie kompleksowych projektów z za- } \\
\text { kresu ochrony siedlisk przyrodniczych (eko- } \\
\text { systemów) na obszarach chronionych oraz } \\
\text { zachowanie różnorodności gatunkowej }\end{array}$ & 58,82 & 50,00 \\
\hline & 5.3. Opracowanie planów ochrony & 12,73 & 10,82 \\
\hline & $\begin{array}{l}\text { 5.4. Kształtowanie postaw społecznych sprzyjaja- } \\
\text { cych ochronie środowiska, w tym różnorodno- } \\
\text { ści biologicznej }\end{array}$ & 10,56 & 8,98 \\
\hline
\end{tabular}

Źródło: Opracowanie własne na podstawie danych źródłowych PO liś. 
Drugi program to Program Operacyjny Współpracy Transgranicznej 2007-2013 Polska - Brandenburgia (województwo lubuskie), a w nim osie priorytetowe:

- $\quad$ wspieranie infrastruktury oraz poprawa stanu środowiska ze środkami 69,51 mln euro,

- wspieranie powiązań gospodarczych oraz współpracy sektorów gospodarki i nauki z 12,15 mln euro z EFRR.

W ramach PO IiŚ jednostki PGL LP zostały zakwalifikowane jako beneficjenci w siedmiu działaniach zawartych w trzech osiach priorytetowych (tab. 2). Najwięcej środków $(665,04 \mathrm{mln}$ euro) dostępnych jest w trzeciej osi priorytetowej, w tym 607,05 mln euro w działaniu 3.1 Retencjonowanie wody i zapewnienie bezpieczeństwa przeciwpowodziowego.

\section{Wykorzystane środki finansowe przez PGL LP}

W latach 2004-2006 PGL LP wykorzystało środki finansowe w kwocie 52,134 mln zł w działaniu 226 Sektorowego Programu Operacyjnego „Restrukturyzacja i modernizacja sektora żywnościowego oraz rozwój obszarów wiejskich 2004-2006" (SPO PROW 2004-2006). Do instytucji wdrażającej (Agencji Restrukturyzacji i Modernizacji Rolnictwa) nadleśnictwa złożyły 57 wniosków, w tym 53 z terenów województwa warmińsko-mazurskiego i po dwa z opolskiego i lubuskiego na łączną sumę (podpisane umowy) 52,563 mln zł. Rozliczono wnioski dla schematu A - 34,771 mln zł i schemat B - 17,363 mln zł [www. arimr.gov.pl].

Największe fundusze - 513,976 mln zł PGL LP uzyskały z Programu Rozwoju Obszarów Wiejskich z drugiej osi priorytetowej, działanie 226, a następnie z programu PO IiŚ - 397,718 mln zł (rys. 3). W pozostałych programach operacyjnych jednostki PGL LP także uzyskały znaczące środki (podpisały umowy na realizacje zadań): RPO - 10,510 $\mathrm{mln}$ zł, PO EWT $-11,359 \mathrm{mln}$ zł i LIFE+ - 39,475 mln zł [www.ckps.lasy.gov.pl), www.arimr.gov.pl/uploads/media/21022014_Odtwarzanie 7-13.pdf].

W ramach PO PROW 234 w latach 2009-2013 nadleśnictwa złożyły 549 wniosków na łączną sumę $1035,795 \mathrm{mln}$ zł, z czego podpisano 374 umowy na kwotę 513,976 mln zł (tab. 3).

Najwięcej umów (111) podpisano w 2012 roku, w pierwszym naborze w 2009 roku 100 wniosków ze 169 złożonych uzyskało akceptacje i wynikało to z puli przeznaczonych środków. We wszystkich transzach najwięcej (190) podpisanych umów dotyczyło wniosków złożonych według schematu II na wzmocnienie systemu ochrony przeciwpożarowej obszarów leśnych, a 138 według sche- 




\section{Rysunek 3}

Uzyskane środki przez jednostki PGL LP z programów krajowych na lata 2007-2013

Źródło: Opracowanie własne na podstawie danych źródłowych instytucji wdrażających.

\section{Tabela 3}

Wykorzystanie środków przez nadleśnictwa z PO PROW 2007-2013

\begin{tabular}{|c|c|c|c|c|}
\hline $\begin{array}{c}\text { Rok } \\
\text { naboru }\end{array}$ & $\begin{array}{c}\text { Liczba } \\
\text { wniosków }\end{array}$ & $\begin{array}{c}\text { Wnioskowana kwota pomocy } \\
{[\mathrm{mln} \text { zł] }}\end{array}$ & $\begin{array}{c}\text { Liczba } \\
\text { podpisanych umów }\end{array}$ & $\begin{array}{c}\text { Kwota umowy } \\
{[\mathrm{mln} \text { zł] }}\end{array}$ \\
\hline 2009 & 169 & 368,623 & 100 & 181,084 \\
\hline 2010 & 107 & 145,434 & 89 & 92,000 \\
\hline 2012 & 116 & 221,201 & 111 & 149,210 \\
\hline 2013 & 157 & 300,537 & 74 & 91,501 \\
\hline Razem & 549 & 1035,795 & 374 & 513,796 \\
\hline
\end{tabular}

Źródło: Opracowanie na podstawie danych ARiMR, www.arimr.gov.pl.

matu I. Część nadleśnictw zakwalifikowanych do obu schematów podpisało 17 umów obejmujących cały zakres kosztów kwalifikowanych.

Według danych ARiMR na dzień 5.02.2014 roku, agencja rozliczyła już 204 umowy podpisane w latach 2009-2012 na łączną sumę 249,469 mln zł. Rozliczono 97 umów (ze 100 podpisanych) z 2009 roku na sumę 161,529 mln zł i 71 z 2010 roku na 61,748 mln zł oraz 36 z 2012 roku na 26,192 mln zł. Największą sumę 10,027 mln zł rozliczyło Nadleśnictwo Lubaczów, następnie Nadleśnictwo Rudzieniec - 7,917 mln zł i Nadleśnictwo Myszyniec - 7,824 mln zł. Najwięcej (121) rozliczonych umów zawierało się w kwocie do $2 \mathrm{mln}$ zł (72 do miliona złotych i 49 do $2 \mathrm{mln}$ zł). Całkowita wypłacona suma środków (obejmująca także płatności pośrednie) przez ARiMR z działania 226 na dzień 21.02.2014 roku wynosi 275,459 mln zł [http:/www.arimr.gov.pl/uploads/media/21022014_Odtwarzanie_7-13.pdf].

W ramach 10 RPO 2007-2013 nadleśnictwa uzyskały dofinansowanie na realizację działań związanych z gospodarką leśną, z czego największe środki 
(2,706 mln zł) wykorzystano z RPO Podlasia (nadleśnictwa Żednia, Rudka, Supraśl). W pozostałych RPO województw uzyskano: dolnośląskie - 2,285; lubelskie - 1,903; podkarpackie - 1,336; wielkopolskie - 0,915; kujawsko-pomorskie - 0,719; małopolskie - 0,283; świętokrzyskie - 0,176; zachodniopomorskie $-0,097$ i warmińsko-mazurskie $-0,085 \mathrm{mln}$ zł [www.ckps.lasy.gov. pl]. W ramach RPO Podlasia Nadleśnictwo Supraśl realizowało zadanie z osi priorytetowej III „Rozwój turystyki i kultury” działanie 3.1 „Rozwój atrakcyjności turystycznej regionu” - z sumą dofinansowania 1,126 mln zł pt. „Utworzenie szlaku powstania styczniowego w Puszczy Knyszyńskiej”. W ramach osi V, działanie 5.2 RPO Podlasie trzy nadleśnictwa finansują działania związane z odnawialnymi źródłami energii [http://www.rpowp.wrotapodlasia.pl/private /upload/file/2c88e37633aafe5f6592da1604df6c6d.pdf]. Dobrym przykładem wykorzystania środków w ramach konkursów z RPO na lata 2007-2013 są również wnioski zatwierdzone do realizacji z nadleśnictw: Biłgoraj $(0,251$ mln zł), Kielce $(0,1934 \mathrm{mln}$ zł), Jarocin $(0,262 \mathrm{mln}$ zł), Sieraków $(0,279 \mathrm{mln}$ zł) i Łopuchówko $(0,278 \mathrm{mln} z ł)$.

$\mathrm{W}$ ramach działania $5.1 \mathrm{z} \mathrm{V}$ osi priorytetowej PO IiŚ jednostki PGL LP uzyskały dofinansowanie w wysokości 30,496 mln zł, w tym: 23,996 mln zł (całkowita suma wniosków 32,527 mln zł) 11 nadleśnictw na realizacje 16 projektów i 6,500 mln zł trzy RDLP (Krosno, Kraków, Toruń) w ramach czterech projektów. Prowadzone przez nadleśnictwa działania miały na celu ochronę obszarów przyrodniczo cennych i siedlisk oraz budowę małej infrastruktury (turystycznego zagospodarowania lasu) służącej zabezpieczeniu obszaru Natura 2000. Projekty realizowane przez RDLP dotyczyły ochrony żubra i cisa pospolitego (Taxus baccata L.), a RDLP w Gdańsku zrealizowała projekt „Plany ochrony rezerwatów na terenie RDLP w Gdańsku" finansowany z działania 5.3 „Opracowanie planów ochrony” V osi PO IiŚ na łączną sumę $1,131 \mathrm{mln}$ zł z dofinansowaniem $0,946 \mathrm{mln}$ zł z UE. Największym dofinansowaniem z PO IiŚ objęto trzy projekty indywidualne realizowane przez Centrum Koordynacji Projektów Środowiskowych (CKPŚ) z poziomu DGLP w ramach osi priorytetowej II i III:

- Rekultywacja na cele przyrodnicze terenów zdegradowanych, popoligonowych i powojskowych zarządzanych przez PGL LP z udziałem 57 nadleśnictw i dofinansowaniem w kwocie 96,421 mln zł. Działania prowadzone będą na powierzchni 24289 ha;

- Zwiększanie możliwości retencyjnych oraz przeciwdziałanie powodzi i suszy w ekosystemach leśnych na terenach nizinnych. Działaniem objęty będzie teren 178 nadleśnictw z wykonaniem 3300 obiektów retencyjnych, a planowane dofinansowanie wyniesie $135 \mathrm{mln}$ zł; 
- Przeciwdziałanie skutkom odpływu wód opadowych na terenach górskich. Zwiększenie retencji i utrzymanie w dobrym stanie potoków oraz związanej z nimi infrastruktury. Przewidziany jest udział 55 nadleśnictw i wykonanie 3500 obiektów z dofinansowaniem w kwocie 119 mln zł [DGLP 2013].

Zaawansowanie $\mathrm{w}$ realizacji projektów indywidualnych przedstawiono w tabeli 4.

Tabela 4

Zaawansowanie w realizacji projektów indywidualnych PGL LP z PO liŚ

\begin{tabular}{|c|c|c|c|c|c|}
\hline Program & $\begin{array}{c}\text { Zaawansowanie } \\
\text { finansowe według } \\
\text { kosztów kwalifiko- } \\
\text { wanych } \\
{[\%]}\end{array}$ & $\begin{array}{c}\text { Zaawansowanie } \\
\text { rzeczowe } \\
{[\%]}\end{array}$ & $\begin{array}{c}\text { Wykonane } \\
\text { obiekty }\end{array}$ & $\begin{array}{c}\text { Ilość retencjo- } \\
\text { nowanej wody } \\
{\left[\mathrm{m}^{3}\right]}\end{array}$ & $\begin{array}{c}\text { Środki } \\
\text { wypłacone } \\
\text { z NFOŚiGW } \\
{[\mathrm{zł}]}\end{array}$ \\
\hline MNR & 45,29 & 50,80 & $1825 \mathrm{szt}$. & 10121830 & $21794592 \mathrm{zt}^{*}$ \\
\hline MRG & 16 & 39,00 & $1360 \mathrm{szt}$. & 344468 & $6200000 \mathrm{zł}^{* *}$ \\
\hline POL & 12,43 & 16,48 & 4002,39 ha & - & $7918815 \mathrm{zt}^{* * *}$ \\
\hline
\end{tabular}

* Stan realizacji Mała Retencja Nizinna (MRN) - nadleśnictwa przedłożyły do CKPŚ wydatki na kwotę ok. 75,5 mln zł, w tym: 4,130 mln zł jako niekwalifikowane, 11,5 mln zł oczekuje na weryfikację procedury OOŚ przez NFOŚiGW, w ramach wniosku o płatność (WOP) przedłożono wydatki w wysokości 60,132 mln zł [DGLP 2013].

** Stan realizacji Mała Retencja Górska (MRG) - nadleśnictwa przedłożyły do CKPŚ wydatki na kwotę 45,973 mln zł, w tym: wydatki niekwalifikowane - 0,135 mln zł, kwota 26,520 mln zł oczekuje na weryfikację procedury OOŚ przez NFOŚiGW, w ramach WoP przedłożono wydatki w wysokości 19,317 mln zł [DGLP 2013].

${ }^{* * \star}$ Stan realizacji Poligony (POL) - nadleśnictwa przedłożyły do CKPŚ wydatki kwalifikowane na kwotę 14,097 mln zł, w tym: 4,736 mln zł zatwierdzone przez CKPŚ oraz 1,442 mln zł w trakcie weryfikacji/uzupełnień w CKPŚ [DGLP 2013].

Źródło: Opracowanie własne na podstawie „Sprawozdanie finansowo-gospodarcze PGL LP za 2012 rok".

W ramach programu LIFE+ i dofinansowania z NFOŚiGW realizowane są centralnie przez CKPŚ w PGL LP dwa tematy związane z podniesieniem świadomości społeczeństwa o zagrożeniu pożarowym w lesie i jeden $\mathrm{z}$ ochroną różnorodności biologicznej na obszarach leśnych, których łączne dofinansowanie z UE wynosi 2686627 i 2322268 euro ze środków krajowych (tab. 5) [http:// www.ogienwlesie.lasy.gov.pl/home, http://www.bestpractice-life.pl/].

Jednostki PGL LP realizują również działania z PO EWT jako beneficjent wiodący lub jako partnerzy programów realizowanych przez zagraniczne instytucje. Na uwage zasługują dwa wnioski przygotowane i realizowane przez same nadleśnictwa Wymiarki - dofinansowanie 691548 euro i Świeradów Zdrój $767550 \mathrm{zl}$ (tab. 6). 
Tabela 5

Realizowane przez PGL LP tematy i ich dofinansowanie z programu LIFE+ i NFOŚiGW

\begin{tabular}{|c|c|c|c|c|}
\hline \multirow{2}{*}{ Nr działania } & \multirow{2}{*}{ Temat } & \multirow{2}{*}{$\begin{array}{l}\text { Całkowity } \\
\text { budżet } \\
\text { projektu }\end{array}$} & \multicolumn{2}{|c|}{ Wsparcie finansowe $z$} \\
\hline & & & UE & NFOŚiGW \\
\hline LIFE08 INF/PL/000523 & $\begin{array}{l}\text { FORESTFIRE - Ogień w lesie } \\
\text { a przyroda - podniesienie świa- } \\
\text { domości mieszkańców terenów } \\
\text { wiejskich w zakresie zapobiega- } \\
\text { nia pożarom lasów }\end{array}$ & 1987381 & 889544 & 894400 \\
\hline LIFE09 INF/PL/000275 & $\begin{array}{l}\text { FORESTFIRE II - Ogień w lesie } \\
\text { a przyroda II - drugi etap kam- } \\
\text { panii informującej społeczeń- } \\
\text { stwo o zagrożeniu pożarowym } \\
\text { w lasach }\end{array}$ & 1500377 & 750188 & 605973 \\
\hline LIFE10 INF/PL/000673 & $\begin{array}{l}\text { Ochrona różnorodności biolo- } \\
\text { gicznej na obszarach leśnych, } \\
\text { w tym w ramach sieci Natura } \\
2000 \text { - promocja najlepszych } \\
\text { praktyk }\end{array}$ & 2093790 & 1046895 & 821895 \\
\hline & Razem & 5581548 & 2686627 & 2322268 \\
\hline
\end{tabular}

Źródło: http://www.ogienwlesie.lasy.gov.pl/home, http://www.bestpractice-life.pl/

Tabela 6

Wybrane działania realizowane przez jednostki PGL LP dofinansowane z PO EWT

\begin{tabular}{|c|c|c|c|}
\hline $\begin{array}{l}\text { Program EWT } \\
2007-2013\end{array}$ & Temat działania & Wsparcie & $\begin{array}{l}\text { Realizowany } \\
\text { przez: }\end{array}$ \\
\hline Polska-Saksonia & $\begin{array}{l}\text { Utworzenie centrum spotkań leśników } \\
\text { polskich i niemieckich w Wymiarkach }\end{array}$ & $\begin{array}{l}691548 \\
\text { euro }\end{array}$ & $\begin{array}{l}\text { Nadleśnictwo } \\
\text { Wymiarki }\end{array}$ \\
\hline $\begin{array}{l}\text { Czeska Republika- } \\
\text {-Rzeczpospolita } \\
\text { Polska }\end{array}$ & $\begin{array}{l}\text { Czesko-polski singltrek pod Smrkem } \\
\text { w Górach Izerskich }\end{array}$ & $767550 \mathrm{zł}$ & $\begin{array}{l}\text { Nadleśnictwo } \\
\text { Świeradów } \\
\text { Zdrój }\end{array}$ \\
\hline $\begin{array}{l}\text { Krajów } \\
\text { Meklemburgia- } \\
\text {-Pomorze Przednie/ } \\
\text { /Brandenburgia } \\
\text { i Rzeczpospolitej } \\
\text { Polskiej } \\
\text { (województwo } \\
\text { zachodniopomorskie) }\end{array}$ & $\begin{array}{l}\text { Opracowanie transgranicznego syste- } \\
\text { mu wspomagania procesów decyzyj- } \\
\text { nych dla zdalnej i modelowej oceny } \\
\text { biomasy drzewnej w lasach obszaru } \\
\text { wsparcia POMERANIA }\end{array}$ & $\begin{array}{l}161500 \\
\text { euro }\end{array}$ & $\begin{array}{l}\text { RDLP Szczecin } \\
\text { Nadleśnictwo } \\
\text { Drawno }\end{array}$ \\
\hline Południowy Bałtyk & $\begin{array}{l}\text { Hardwoods are good - wsparcie przed- } \\
\text { siębiorstw zwiazanych z produkcja } \\
\text { i przerobem drewna liściastego w base- } \\
\text { nie Bałtyku Południowego }\end{array}$ & brak danych & RDLP Gdańsk \\
\hline
\end{tabular}


cd. tabeli 6

\begin{tabular}{|l|l|c|l|}
\hline $\begin{array}{l}\text { Program EWT } \\
\text { 2007-2013 }\end{array}$ & \multicolumn{1}{|c|}{ Temat działania } & Wsparcie & $\begin{array}{l}\text { Realizowany } \\
\text { przez: }\end{array}$ \\
\hline \multirow{2}{*}{$\begin{array}{l}\text { Rzeczpospolita } \\
\text { Polska-Republika } \\
\text { Słowacka }\end{array}$} & $\begin{array}{l}\text { Rewitalizacja beskidzkich lasów na pol- } \\
\text { sko-słowackim pograniczu, w celu po- } \\
\text { prawy ich społecznych, ekologicznych } \\
\text { i przeciwpowodziowych funkcji }\end{array}$ & $\begin{array}{c}276308 \\
\text { euro }\end{array}$ & $\begin{array}{l}\text { RDLP Katowice } \\
\text { Nadleśnictwo } \\
\text { Wisła, Ujsoły, } \\
\text { Jeleśnia }\end{array}$ \\
\cline { 2 - 4 } & $\begin{array}{l}\text { Polsko-Słowackie Centrum Turystyki } \\
\text { Konnej }\end{array}$ & 6599 euro & $\begin{array}{l}\text { Nadleśnictwo } \\
\text { Rymanów }\end{array}$ \\
\cline { 2 - 4 } & $\begin{array}{l}\text { Międzynarodowa leśna ścieżka dydak- } \\
\text { tyczna Udava-Solinka }\end{array}$ & brak danych & $\begin{array}{l}\text { Nadleśnictwo } \\
\text { Cisna }\end{array}$ \\
\hline $\begin{array}{l}\text { Region Morza } \\
\text { Bałtyckiego }\end{array}$ & $\begin{array}{l}\text { Bałtycki krajobraz - innowacyjne podej- } \\
\text { ście do zrównoważonych krajobrazów }\end{array}$ & $\begin{array}{l}550150 \text { zł } \\
\text { brak danych }\end{array}$ & $\begin{array}{l}\text { RDLP Poznań } \\
\text { RDLP Olsztyn }\end{array}$ \\
\hline
\end{tabular}

Źródło: Opracowanie własne na podstawie danych z nadleśnictw i stron internetowych programów EWT.

\section{Wykorzystanie środków przez przykładowe RDLP i nadleśnictwa PGL LP}

Zróżnicowanie w uzyskanym dofinansowaniu środków wśród jednostek PGL LP jest znaczne i w dużej mierze zależy od zaangażowania i determinacji poszczególnych pracowników i nadleśniczych. Wiele nadleśnictw, które tak jak np. Nadleśnictwo Świeradów Zdrój (suma dotacji 9,034 mln zł - tabela 7) z RDLP Wrocław czy Bartoszyce (5,957 mln zł), RDLP Olsztyn oraz Łopuchówko z RDLP Poznań (ok. 4,096 mln zł), uzyskiwało dofinansowanie z różnych programów.

Bardzo korzystny bilans poszczególnych regionalnych dyrekcji LP w uzyskiwaniu środków zewnętrznych zapewniły nadleśnictwa, jednak nie można zapomnieć o środkach, które uzyskano z poziomu RDLP. Bilans środków $135,166 \mathrm{mln}$ zł na realizacje działań, przy współfinansowaniu z funduszy UE, przez jednostki RDLP we Wrocławiu jest imponujący, w tym z przeważająca rolą dwóch programów PO IiŚ (w ramach projektów indywidualnych PGL LP) i PO PROW działanie 226 (tab. 8).

Autorzy są świadomi, że pomimo wielu starań nie byli w stanie przedstawić wszystkich uzyskanych środków przez jednostki PGL LP (430 nadleśnictw, 17 RDLP i 7 zakładach krajowych) z dostępnych programów i działań z perspektywy finansowej 2007-2014. Można by tu wspomnieć o środkach uzyskanych przez ORWLP w Bedoniu na szkolenia straży leśnej, o finansowaniu w wysokości 2,553 mln zł działań Leśnego Banku Genów w Kostrzycy z MF EOG (decyzja z 11.03.2014) czy wielu innych. 




\section{Wnioski}

Uzyskane środki finansowe umożliwiały realizację zadań, które przyczyniły się do ochrony obszarów leśnych, a zwłaszcza ich cennych siedlisk, zabezpieczenia przeciwpożarowego oraz poprawy infrastruktury turystycznej służącej społeczeństwu.

Nadleśnictwa PGL LP realizując działania związane z rekreacyjnym i turystycznym zagospodarowaniem lasu przyczyniają się do rozwoju infrastruktury lokalnej.

Jednostki PGL LP - nadleśnictwa, regionalne dyrekcje oraz inne potrafią dobrze aplikować o środki z różnych programów, a co najważniejsze, także dobrze je zrealizować i rozliczyć.

Przykładem dobrego wykorzystania środków i kontynuacji działań przez jednostki PGL LP może być PO PROW z lat 2004-2006 i 2007-2013 działanie 226 „Odtwarzanie potencjału produkcji leśnej zniszczonego przez katastrofy oraz wprowadzanie instrumentów zapobiegawczych”.

Przed PGL LP w przyszłości stoi wiele zadań związanych z realizacją funkcji społecznych i ekologicznych lasu czy adaptacją lasów i leśnictwa do zachodzących zmian klimatu. Wskazuje to na konieczność umożliwienia jednostkom PGL LP starania się o środki z funduszy UE w kolejnej perspektywie finansowania na lata 2014-2020.

\section{Literatura}

ŁADYKA S., 2007: Pół wieku Unii Europejskiej - nowe wyzwania, XII Ogólnopolska Konferencja Naukowa „Unia Europejska w gospodarce światowej - nowe uwarunkowania, SGH Warszawa.

DGLP 2013: Sprawozdanie finansowo-gospodarcze PGL LP za 2012 rok, DGLP, Warszawa.

Program Europejska Współpraca Terytorialna Krajów Meklemburgia-Pomorze Przednie/ /Brandenburgia i Rzeczpospolitej Polskiej (województwo zachodniopomorskie).

Program Operacyjny Współpracy Transgranicznej 2007-2013 Polska-Brandenburgia (województwo lubuskie).

Rozporządzenie Ministra Rolnictwa i Rozwoju Wsi z dnia 20 maja 2008 w sprawie szczegółowych warunków i trybu przyznawania pomocy finansowej w ramach działania „Odtwarzanie potencjału produkcji leśnej zniszczonego przez katastrofy oraz wprowadzenie instrumentów zapobiegawczych" objętego Programem Rozwoju Obszarów Wiejskich na lata 2007-2013 (Dz.U. Nr 103, poz. 658).

Rozporządzenie Ministra Rolnictwa i Rozwoju Wsi z dnia 8 września 2004 r. w sprawie uzupełnienia Sektorowego Programu Operacyjnego „Restrukturyzacja i modernizacja sektora żywnościowego oraz rozwój obszarów wiejskich 2004-2006”. (Dz.U. Nr 207, poz. 2117). 
TRZCIŃSKI G. 2009: Możliwości wykorzystania środków finansowych z Europejskiego Funduszu Rozwoju Regionalnego przez Państwowe Gospodarstwo Leśne Lasy Państwowe, Sylwan 153(10), s. 689-698.

www.arimr.gov.pl

www.//www.arimr.gov.pl/uploads/media/21022014_Odtwarzanie_7-13.pdf

www.//europa.eu/about-eu/eu-history/1945-1959/foundingfathers/schuman/index_pl.htm

www.funfuszeeuropejskie.gov.pl

www.nfosigw.gov.pl

www.ckps.lasy.gov.pl

www.//www.ckps.lasy.gov.pl/dla-jednostek-pgl-lp\#.UzMmf2dOWt8

www.mrr.gov.pl

www.//www.rpowp.wrotapodlasia.pl/private/upload/file/2c88e37633aafe5f6592da1604

df6c6d.pdf

\title{
The implementation of multifunctional forest management by the State Forests National Forest Holding with use of European funds
}

\begin{abstract}
In the following paper the authors provide an analysis of the possibility of implementing by the State Forests National Forest Holding (PGL LP) a multifunctional, sustainable forest management based on the principles of environmental protection, co-financed from EU funds and national programs in the 2007-2013 funding perspective. The following national programs were taken into account: Regional Operational Programmes, Infrastructure and Environment Operational Programme, Rural Development Programme, European Territorial Cooperation Programme. The programmes were analysed to the extent where the State Forests units (Forest Districts, Regional Directorates of National Forest, State Forests of National Forest) were beneficiaries of financial funds. The analysis of the use of funds by the State Forests units, accompanied by a general statement and selected projects was performed. The issues related to direct payments in the study were not taken into account.
\end{abstract}


